\title{
Existing production and marketing system of fodder under Meherpur district as livelihood activity
}

\author{
B. K. Roy*, N. R. Sarker, M. K. Alam \& K. S. Huque \\ Bangladesh Livestock Research Institute, Savar, Dhaka-1341 \\ *Corresponding author: biplobkroy@yahoo.com
}

\begin{abstract}
An investigation was carried out with the objectives to determine the existing production and marketing system of fodder as a livelihood activity of farmers under Meherpur district. For this, a purposive survey was conducted covering three Upazilas' of Meherpur district namely, Meherpur Sadar, Gangni and Mujibnagar. Before conducting the survey, a Focus Group Discussion (FGD) was arranged and it was identified that there were three stakeholders involved under these areas: fodder producers, middlemen and users of fodder. On the basis of the findings of FGD, a survey was conducted through a pre-tested structured questionnaire as per objectives of the survey. Data were collected randomly from 33 Napier producers, 18 middlemen and 64 fodder users. Survey results indicated that, the average number of cattle and goat per household was 2.12 and 3.19 , respectively, while on the other hand none of the farmers under the study areas reared sheep. Sharing of major household income implied that, majority of the fodder producers (72.72\%) depended on their livelihood on Napier production and about $83.33 \%$ middlemen depends their livelihood on fodder marketing. However, the major sources of income of dairy keepers were business (39.06\%), fodder production $(20.31 \%)$ and agriculture $(12.50 \%)$. The annual total biomass production of Napier per hectare was 314.48 metric tons. About $45 \%$ producers sold green Napier grass in the market, $30 \%$ supply directly to middlemen and the rest of $25 \%$ farmers marketed their produces directly in market and to middlemen. The prices of a bundle of Napier grass were varied from Tk. 3.00-4.00 to 5.00-6.00, respectively during summer and winter. The total cost, gross income and net profits for Napier production were Tk. 2,37,934.00, Tk. 4,71,723.00 and Tk. 2,33,789.00 per hectare per year, respectively. The benefit cost ratio (BCR) for Napier cultivation was 1.98:1. It can be concluded that fodder production and marketing system in Meherpur district is a profitable enterprises and all the stakeholders under this production and marketing system are getting monetary benefits.
\end{abstract}

(Key words: Fodder, Napier, Production, Marketing, Livelihood)

\section{Introduction}

Livestock is an integral part of the farm economy of Bangladesh (Jabber, 2003). Livestock keeping in Bangladesh is integrated with mixed crop-livestock farming system. The most important livestock are cattle and buffaloes; in addition, cattle and other livestock supply vital dietary animal protein through milk, meat, and eggs for human consumption and help alleviating the protein deficiencies prevalent in Bangladesh (Sayeed et al. 2008). Bangladesh has a very high density of population considering the total land mass and the cultivable land. Livestock development is mainly constrained by three factors, deficiency in feed and fodder resources and poor nutritive of these feed- stuffs, prevalence of wide spread diseases and poor genetic quality of livestock species and hence low productivity (Sayeed et al. 2008). The main feeds available to ruminants are crop residues, agro-industrial by-products, leaves from trees and native grasses from roadside verges, paddy bunds and fallows (Islam, 1992). In Bangladesh $84 \%$ of the total land area is used for cereal 
cultivation, mainly rice. Rice straw and bran contribute $90 \%$ of the energy available for ruminants. However, only $40 \%$ straw production is used as ruminant feed. The remainder is accounted for alternative uses such as fuel and compost, miscellaneous uses and losses in storage during the wet season (Devendra et al. 2000).

In Bangladesh, there is a requirement of 70 million metric tons of green grass for cattle feed in a year but produced only 24 million metric tons. Thus, there is a deficit of animal feeds for about 60 percent, which are hamparing the livestock development to a great extent (Daily Prothom Alo, 2008). Scarcity of feeds and fodder for livestock production is a major problem in Bangladesh (Rahman, 2011) and the situation is mostly aggravated during the lean period. The lack of fodder is one of the major limiting factors for increasing milk production on small-scale dairy farms (Alam, 2006). Bangladesh having about 0.21 acres per capita net cropped area and an annual increase of 1.50 million working age people needs strategic exploration of livestock resources for alleviating rural poverty, ensuring food security and creating employment opportunities (Huque and Huque, 1997). The main constraint to forage production for feeding ruminants is the scarcity of land. Usually farmers do not want to spare cultivable land for fodder production instead of crop production (Sayeed et al. 2008).

Recently, fodder production gets momentum as an income generation and employment opportunity in certain areas of Bangladesh, especially milk pocket areas, namely Madaripur, Munshigonj, Rangpur, Sirajgonj and Tangail where small scale dairying, fattening and milk marketing facilities are prevailed (Sayeed et al. 2008). Meherpur district is one of the examples of the above. Some of the innovative farmers in this district are acting as pioneer of fodder production and marketing through introduction of Napier cuttings from Bangladesh Livestock Research Institute (BLRI) and Department of Livestock Services (DLS) in this region. In 1999, an innovative farmer of Meherpur district have started cultivating Napier grass as an experimental basis covering 16.5 decimal (0.07 ha) of lands and now it's developed as a fodder production model for income generation and employment opportunities. Therefore, present study was undertaken to investigate the existing production and marketing system of fodder as a livelihood activity of farmers under Meherpur district.

\section{Materials and Methods}

In order to achieve the study objectives, a survey was conducted covering three Upazilas' of Meherpur district, Bangladesh namely, Meherpur Sadar, Gangni and Mujibnagar. Before survey, 
BLRI research team visited the study areas; a Focused Group Discussion (FGD) was carried with the farmer and respective DLS extension personnel. Through FGD, it was identified that there were three groups of stakeholders namely fodder producers, middlemen and users of fodder (dairy, fattening and goat keepers) were involved in fodder production and marketing system under Meherpur district. The schematic diagram of existing fodder production and marketing system in Meherpur district are given in Figure 1. On the basis of the findings of FGD, a purposive survey was conducted through a structured pre-tested questionnaire. The pre-tested questionnaires were modified as per the observations during pre-testing the questionnaires. The data were collected from the respondents though personal interview by the researchers. Collected data were rechecked for any missing value and corrected accordingly. However, a total of 115 stakeholders taking 33 Napier cultivators, 18 middlemen and 64 fodder users (dairy keepers) were interviewed randomly. Collected data were processed, analysed and tabulated involving descriptive statistics using Microsoft Excel.

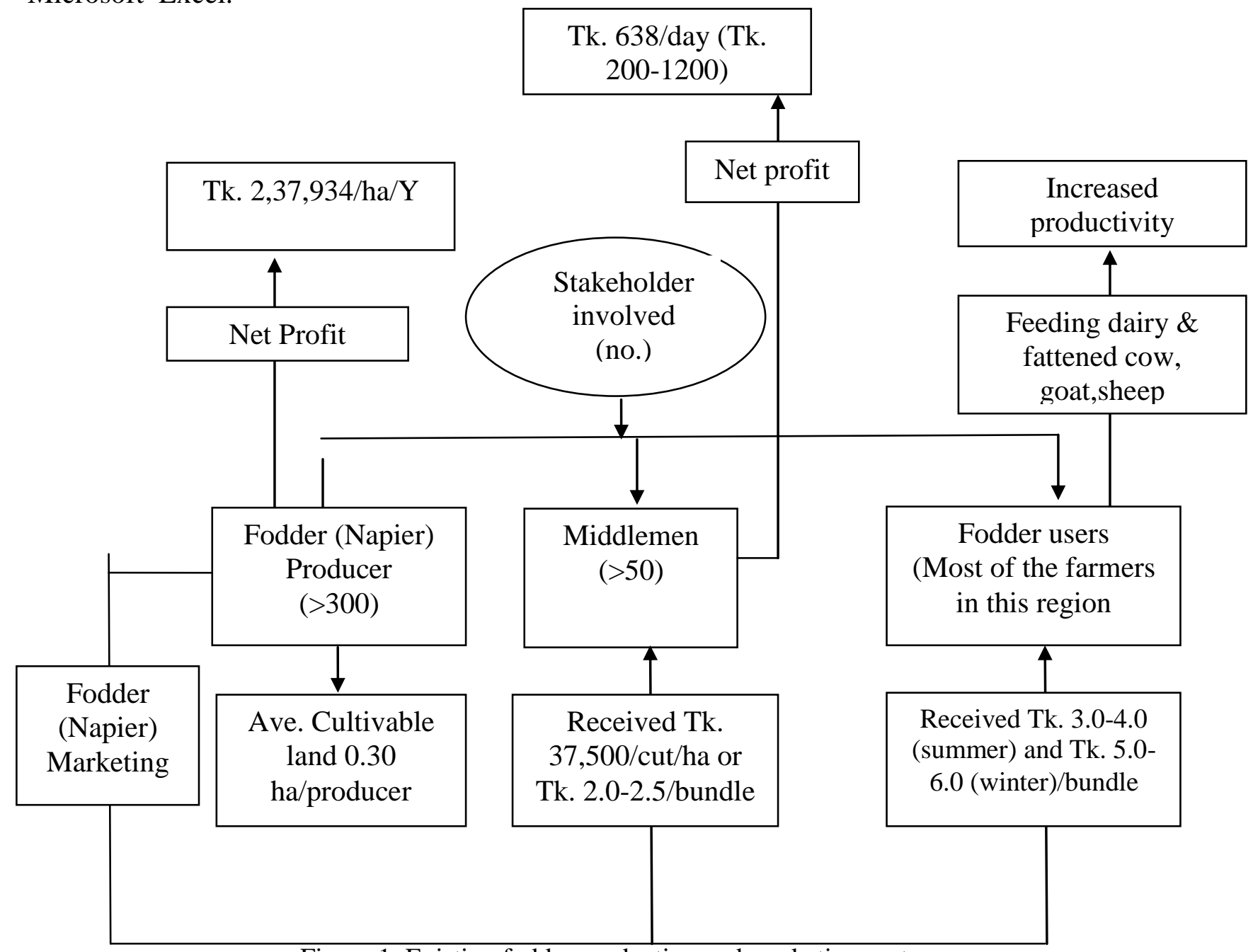

Figure 1: Existing fodder production and marketing system 


\section{Results and discussion}

\section{Household distribution of livestock and farming experience}

The survey results indicated that, the ages of all the three stakeholders were between 38-39 years. The average farming experience as fodder producers, middlemen and dairy keepers was 3.94, 3.12 and 7.89 years of age, respectively. The household distribution of cattle, goat and sheep in Meherpur areas are presented in Table 1. The average number of cattle and goat per household was 2.09 and 3.19, respectively. The average number of cattle and goat per household was slightly higher in the surveyed areas compared to the national average which are 1.02 and 0.68 per household, respectively (BBS, 2012). None of the household under this study reared sheep. However, Sayeed et al. (2008) reported average number of cattle; goat and sheep per household were 7.82, 1.07 and 0.1,3 respectively in some selected milk pocket areas of Bangladesh.

\section{Table 1. Distribution of cattle and goat in surveyed household}

\begin{tabular}{llccc}
\hline \multirow{2}{*}{ Ruminant animal } & \multicolumn{3}{c}{ Average number } \\
\cline { 3 - 4 } & & \multicolumn{2}{c}{ Breed } & Total \\
\cline { 3 - 4 } & & Local & Cross & 2.09 \\
\hline A. $\quad$ Cow & 1.24 & 0.85 & 0.39 \\
& Milking cow & 0.22 & 0.17 & 0.23 \\
& Dry cow & 0.13 & 0.10 & 0.31 \\
& Heifer & 0.14 & 0.17 & 0.78 \\
& Bull & 0.58 & 0.20 & 0.38 \\
& Calf & 0.17 & 0.21 & 3.19 \\
\hline
\end{tabular}

\section{Trend of fodder production}

It is noted that under this existing fodder production and marketing system, $40 \%$ fodder producers started their business just 2-3 years ago, 27\% started 4-5 years earlier, 21\% had more than 5 years experience, and $12 \%$ producers had only 1 year experience on Napier production. The better facilities for market of fodder as well as profits are the main two reasons for gradual expansion of fodder production in this region. According to the producers statement, in 2011, the average area under Napier cultivation in this region was 0.26 ha or 0.64 acres (range $0.00-2.27$ ha) and it was increased at the rate of 15 percent by the year 2012. At present, the average area under Napier cultivation was 0.30 ha or 0.74 acres per household. Interestingly, Sayeed et al. (2008) reported 
almost similar areas for cultivation of fodder by farmers in some selected milk pocket areas of Bangladesh. They reported in their study that the average of land attributed to fodder production by the farmers was $0.67,0.80$ and 0.76 acres in 2005, 2006 and 2007, respectively with an average of 0.74 acres.

\section{Agronomical practices of fodder cultivation}

In general, the land usually used for Napier cultivation in the study areas was almost high/plain $(97 \%)$ and the texture of soil was mostly slity (74\%) and sandy (26\%). Napier cuttings were mostly transplanted during November-December.

\section{Income generation of the stakeholders}

Majority of the fodder producer's (72.72\%) livelihood depends on Napier production. About $83.33 \%$ middlemen maintained their livelihood on fodder marketing. However, the major sources of income of the dairy keepers were business (39.06\%), fodder production $(20.31 \%)$ and agriculture $(12.50 \%)$.

\section{Biomass yield of Napier grass}

During the first year of cultivation, farmers generally harvested fodder 5-6 times, while from $2^{\text {nd }}$ year and onward, the number of harvesting was increased from 6 to 7 times per year. The frequency of harvesting usually faster during summer/rainy season (30-35 days) compared to winter season (45 days intervals). As per statement given by the producers, the total biomass yield per cut per hectare was 22,463 bundles, which was equivalent to 44.93 metric tons of fresh biomass. The average weight in each bundle was $2.0 \mathrm{~kg}$. Survey results indicated that the annual total biomass production per hectare was about 1,57,241 bundles or 314.48 metric tons (Table 2).

\section{Table 2. Biomass yield of Napier grass}

\begin{tabular}{lcc}
\hline Items & \multicolumn{2}{c}{ Biomass yield/ha } \\
\cline { 2 - 3 } & Per cut & Per year (7 cuts) \\
\hline Bundle & 22,463 & $1,57,241$ \\
Weight (Metric tons) & 44.93 & 314.48 \\
\hline
\end{tabular}




\section{Utilization and marketing of Napier grass}

About $37 \%$ cultivators in the study area sold their produces directly both in market or to the middlemen, $6 \%$ used for their own farm and the rest of $57 \%$ producers used Napier for both their own farm and sell it to market (Fig. 2). However, the marketing system of Napier as shown in Fig. 3 revealed that about $45 \%$ producers sold Napier grass in the market, $30 \%$ supply directly to middlemen and the rest of $25 \%$ farmers marketed their produces directly in the market and to middlemen. During summer and winter seasons, the prices of a bundle of Napier grass were varied from Tk. 3.00-4.00 to 5.00-6.00, respectively. Farmers, however, received relatively lower price if they sell it to middlemen and the price vary from Tk. 2.0-2.50 to Tk. 3.50-4.00, respectively (Table 3). Most of the middlemen collected Napier grass directly from farmer's plot at the price of Tk. 30,000-37,000 per cut per hectare and sold it to dairy keepers. Some middlemen under this model purchased grass directly from farmers as bundle and paid Tk. 2.5-3.0 per bundle. It was estimated that a middlemen earned Tk. 638 per day (Range Tk. 200-1200) through selling on an average 1.28 metric ton (640 bundles; range 150-1500 bundles) grass to dairy keepers. A dairy keeper purchased Napier grass on an average of 9.25-bundle $(19 \mathrm{~kg})$ at the cost of Tk. 36 .

\section{Table 3. Price of fodder and income of stakeholders}

\begin{tabular}{lcccc}
\hline \multirow{2}{*}{ Person sell } & \multicolumn{2}{c}{ Price (Tk./bundle) } & \multicolumn{2}{c}{ Gross income (Tk./ha) } \\
\cline { 2 - 5 } & Summer/rainy & Winter & Summer/rainy & Winter \\
\hline Farmers himself & $3.0-4.0$ & $5.0-6.0$ & $67,390-89,853$ & $1,12,317$ \\
Middlemen & $2.0-2.5$ & $3.5-4.0$ & $44,927-56,158$ & $78,622-89,853$ \\
\hline
\end{tabular}

\section{Cost and benefits of Napier cultivation}

Annual cost and income from Napier grass cultivation in the study area have been shown in Table 4 and 5, respectively. The total operating and variable cost required for Napier production was Tk. 1,79,014 and Tk. 2,00496 per hectare per year, respectively. However, the total cost involved for Napier production was Tk. 2,37,934 per hectare per year. Finally, the gross and net return was Tk. 4,71,723 and Tk. 2,33,789, per hectare per year, respectively. The benefit cost ratio (BCR) for Napier production was 1.98:1, indicating that Napier grass production under Meherpur district was profitable. Sayeed et al. (2008) who reported a relatively higher BCR i.e. 3.17 for harvested Napier in some milk pocket areas. Huque and Islam (2006) estimated a comparative profitability of HYV rice and Napier in a milk shed area, Baghabari, Sirajgong district. They found that the net return 
received from HYV rice (Tk. 6088/ha) was much lower than that of net return received from Napier Production (Tk. 26,552/ha). Huque et al. (2006) observed that farmer at Sirajgonj milk pocket area earned Tk. 2,47,500.00 from a hectare of land Napier seed cutting sold to other farmers. The authors also reported a higher BCR for Napier than that of some other individual crops. The benefit cost ratio was calculated as 3.40:1, 1.15:1, 1.40:1 and 2.00:1, for Napier, Boro, Mustard and Khesari, respectively.
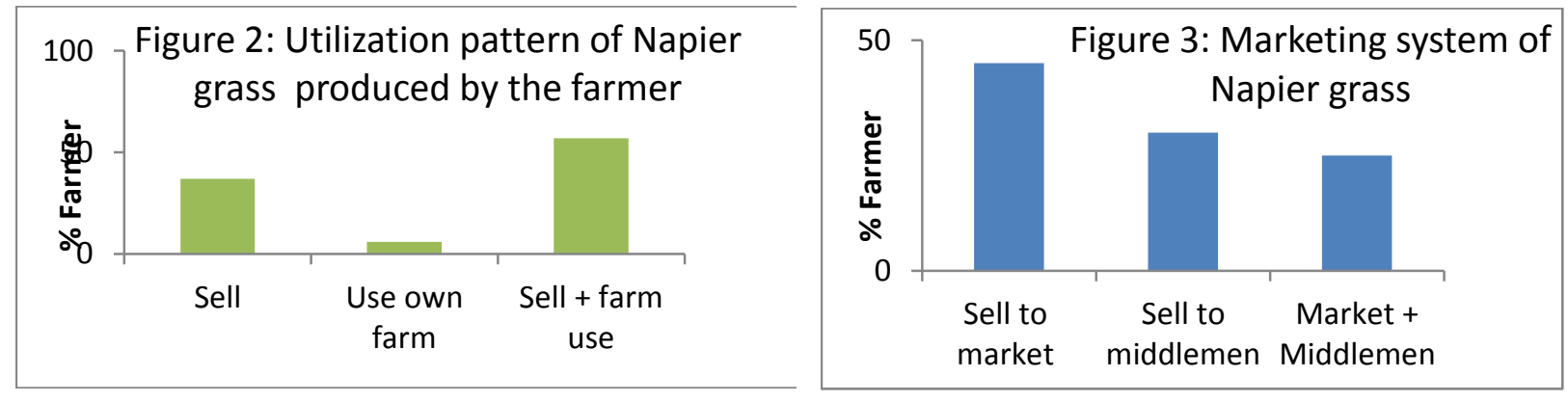

Table 4. Annual cost of production per hectare Napier grass cultivation in the study area

\begin{tabular}{llll}
\hline Items & Unit & Cost/Unit (Tk.) & $\begin{array}{l}\text { Total cost } \\
\text { (Tk./ha) }\end{array}$ \\
\hline Land preparation & & & \\
\hline (a) Ploughing & 4 & @ Tk. 1200 & 4,800 \\
(b) Labour & 30 & @ Tk. 150/labor & 4,500 \\
() Cow dung/manure & 30 trolleys & @ Tk. 500/trolley & 15,000 \\
\hline Fertilizer Application & & & \\
\hline (a) Urea & $262 \mathrm{~kg} / \mathrm{cut}$ & @ Tk. 20/kg & 36,680 \\
(b) DAP & $187 \mathrm{~kg} / \mathrm{cut}$ & @ Tk. 26/kg & 34,034 \\
\hline Irrigation & 3 times/cut & @ Tk. 2200/Irrig. & 46,200 \\
Weeding & 36 labor/cut & @ Tk. 150/labor & 37,800 \\
Operating Cost & - & - & $1,79,014$ \\
Interest on Operating Capital @ 12\% & - & - & 21,482 \\
Total Variable Cost (Tk.) & - & - & $2,00,496$ \\
Fixed Cost: Rental value of land & & & 37,438 \\
Total Cost (Total variable cost plus & - & - & $2,37,934$ \\
total fixed cost) & & & \\
\hline
\end{tabular}


Table 5. Annual income from Napier grass cultivation

\begin{tabular}{lcc} 
& & (Figure in Tk./ha) \\
\hline Items & Per cut & Total \\
\hline Grass production (Tons) & 44.93 & 314.48 \\
Gross income (Tk.) & 67,389 (Tk.3.0/bundle) & $4,71,723$ \\
Net income (Tk) & - & $2,33,789$ \\
Benefit Cost Ratio (BCR) & - & 1.98 \\
\hline
\end{tabular}

\section{Women participation}

The investigation revealed that women participations in fodder production, fodder marketing and dairy farming were $9.09,0.00$ and $59.37 \%$, respectively. Women mainly engaged in weeding for fodder cultivation and supply of feeds and fodder to animal, milking and shed management for dairy farming.

\section{Constraints of fodder production and marketing}

The major constraints faced by the cultivators were unavailability of cutting/seeds in time, lack of training about scientific fodder cultivation, lack of information about high yielding fodder species, and lack of permanent place for fodder marketing. Middlemen also encountered the problem of permanent selling place in the market.

\section{Conclusion}

Indeed, farmers in this region cultivating Napier Bajra (BLRI-1) type grass which was originally developed as well as disseminated from BLRI to DLS. Presently, fodder production and marketing in Meherpur is considered as a profitable enterprise and all the stakeholders involved under this production and marketing system getting economic benefits.

\section{References}

Alam, J., Akteruzzaman, M., Rahman, S. M. A. and Alam, Q. M. 2006. Economics of triticale production as fodder for dairy animals in Bangladesh. Bang. J. Lives. Res., 13: 1-16.

BBS, 2012. Statistical yearbook of Bangladesh. Bangladesh Bureau of Statistics, Statistics and Information Division, Ministry of Planning, Dhaka, Bangladesh. 
Devendra, C., Thomas, D., Jabbar, M. A. and Zerbini, E. 2000. Improvement of livestock production in crop-animal systems in agro-ecological zones of South Asia. ILRI, Nairobi, Kenya.

Huque, K. S. and Islam, M. M. 2006. Impact of napier (Pennisetum purpurim) cultivation on the performance of smallholder dairy in a milk shed area of Bangladesh. Bang. J. Lives. Res., 13: 30-38.

Huque, K. S., Amanullah, S. M. and Islam, M. M. 2006. Impacts of fodder crop introduction into farming systems of selected areas on smallholder dairy development in Bangladesh. Paper presented at the Annual Research Review Workshop, 2006 (June 15 to 16, 2006). Bangladesh Livestock Research Institute, Savar, Dhaka-1341.

Huque, Q. M. E. and Huque, K. S. 1997. Livestock and poultry production in Bangladesh-Problems, Research Achievements and Future Programs. Bangladesh Livestock Research Institute.

Islam, M. A. 1992. A comparative economic analysis of milk cows and buffaloes in two selected village of Mymensingh district in Bangladesh. M.Sc. Thesis. Department of Agricultural Finance, Bangladesh Agricultural University, Mymensingh, Bangladesh.

Jabbar, M.A. 2003. Livestock in food secuirity and poverty alleviation in Bangladesh, First Graduation, Chittagong Govt. Vet. College, University of Chittagong, Bangladesh.

Prothom Alo, 2008. Popular Bangla Daily Newspaper. ঘাস চাষ লাভজনক। 21.06.2008.

Rahman, M.M. 2011. Livestock Feed Marketing in Bangladesh: Problems and Prospects. http://www.studymode.com/essays.

Sayeed, M.A., Rahman, S.M.A., Alam, J., Sarker, N.R. and Begum, J. 2008. An economic study on cultivation of fodder and competing crops in some selected areas of Bangladesh. Research Report, Bangladesh Livestock Research Institute, Savar, Dhaka-1341. 